\title{
Effects of Levels of Primary Plant Nutrients and Row Spacing on Growth and Yield Attributes of Some Promising Varieties of Cluster Bean (Cyamopsis tetragonoloba L.)
}

\author{
Sasmita Priyadarshini ${ }^{1}$, Ghanashyam Singh Rawat $^{1}$ and Sanat Kumar Dwibedi ${ }^{2 *}$ \\ ${ }^{1}$ Rajmata Vijayaraje Scindia Krishi Vishwa Vidyalaya, Gwalior, Madhya Pradesh, India \\ ${ }^{2}$ Orissa University of Agriculture and Technology, Bhubaneswar, Odisha, India \\ *Corresponding author
}

\section{A B S T R A C T}

\begin{tabular}{|l|}
\hline K e y w o r d s \\
$\begin{array}{l}\text { Cluster bean, } \\
\text { Fertility level, Row } \\
\text { spacing, Varieties, } \\
\text { Growth and yield } \\
\text { attributing } \\
\text { characters. }\end{array}$ \\
\hline Article Info \\
\hline $\begin{array}{l}\text { Accepted: } \\
\text { 04 October } 2017 \\
\text { Available Online: } \\
\text { 10 December } 2017\end{array}$ \\
\hline
\end{tabular}

\section{Keywords}

Cluster bean, spacing, Varieties, Growth and yield attributing characters.

Accepted: Available Online: 10 December 2017
A field experiment consisting of 2 fertility levels viz. $50 \%$ of recommended dose of

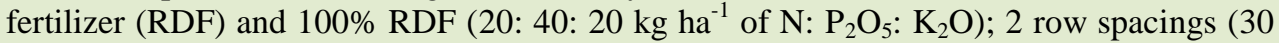
and $45 \mathrm{~cm}$ ) and 3 genotypes [HG-100, HG-8-1 and HG-563(c)] was conducted at the Research Farm, College of Agriculture, Gwalior, India during kharif 2010 to find out their effects on growth and yield attributing characters of cluster bean. The experiment was laid out in factorial randomized block design of $2 \times 2 \times 3$ with 12 treatment combinations and 3 replications. Application of $100 \%$ RDF had better response on growth and yield attributing characters viz. plant height, number of branches, plant-biomass, LAI, number of pods plant $^{-1}$ and seeds pod ${ }^{-1}$ than $50 \%$ RDF. These parameters had also shown positive results under wider row spacing of $45 \mathrm{~cm}$ than $30 \mathrm{~cm}$. Among the tested cultivars cv. HG-100 was the most promising compared to cv. HG-8-1 and cv. HG-563(c). The combined effects of growth and yield contributing characters were ultimately reflected in production of the highest seed yield by sowing of cluster bean cv. HG-100 at $45 \mathrm{~cm}$ row spacing and with $100 \%$ RDF which should be recommended for the farmers of Gird region of Madhya Pradesh, India during kharif.

\section{Introduction}

Cluster bean (Cyamoposis tetragonoloba $\mathrm{L}$. Tabu), an annual kharif arid legume, commonly known as ' guar', was traditionally grown for cattle feed, fodder, medicine and soil improvement. Apart from its present uses as green fodder, vegetable, green manure and grain purposes, its utility in explosive, textile, paper, food, gum and cosmetic industries also fetches foreign currencies. This crop plays great role in nitrogen $(\mathrm{N})$ economy of the succeeding crops though $\mathrm{N}$-fixation from atmosphere and also by addition of organic matter.
Although cluster bean can be grown in nutrient starved soils and in areas of erratic rainfall but growing of improved genotypes with judicious nutrient management have been effective in improving its productivity. Better performance of cluster bean with application of $\mathrm{N}$ and $\mathrm{P}_{2} \mathrm{O}_{5} @ 20$ and $40 \mathrm{~kg} \mathrm{ha}^{-1}$ was reported by Yadav et al., (1991). Rajput (2002) and Priyadarshini et al., (2017) have reported higher yield with recommended dose of fertilizers (RDF) @ 20: 40: $20 \mathrm{~kg} \mathrm{ha}^{-1}$ of N: $\mathrm{P}_{2} \mathrm{O}_{5}: \mathrm{K}_{2} \mathrm{O}$ than $50 \%$ RDF. Proper plant population is the main key for higher yield of 
cluster bean and thus higher yield and quality could be achieved with proper row spacing and plant stand. Rana et al., (1991) and Taneja et al., (1982) reported higher seed yield in $30 \mathrm{~cm}$ row spacing due to more number of plants per unit area and pods plant ${ }^{-1}$. But, crop height, 1000' seed weight and number of seeds pod $^{-1}$ did not differ due to varying row spacing. Though the genotypes have their own ability for growth, development and yield, yet some promising genotypes of guar have shown considerable variations particularly in yield potentials under varying levels of soil fertility. No such work has yet been done to elucidate such interactions between soil fertility, row spacing and genotypes of guar in Gird region of Madhya Pradesh. In view of above scenario, a field experiment was laid out to study the effects of the levels of soil fertility and row spacing on the growth and yield attributing characters of some promising varieties of cluster bean.

\section{Materials and Methods}

\section{Experimental site and climate}

The experiment was conducted during kharif 2010 at the Research Farm of the College of Agriculture, Gwalior, Madhya Pradesh, India located $208 \mathrm{~m}$ above sea level and exactly at $26^{\circ} 13^{\prime}$ 'north latitude and $74^{\circ} 4^{\prime}$ 'east longitude with sub-tropical climate. The summer is extremely hot $\left(46^{\circ} \mathrm{C}\right)$ and winter is chilled reaching at below $1{ }^{0} \mathrm{C}$. The annual rainfall ranges from 650 to $751 \mathrm{~mm}$ with maximum downpour during last week of June to last week of September and drought has been a common phenomenon. The soil was sandy loam having $\mathrm{pH}$, organic carbon, available nitrogen, phosphorous and potash of 8.0, $0.045 \%, 212.5,14.7$ and $282 \mathrm{~kg} \mathrm{ha}^{-1}$, respectively. The cropping history of the site indicated guar-wheat cropping system for last 3 consecutive years.

\section{Experimental design and treatments}

Among the 3 treatments viz. nutrients, spacing and genotypes, the primary plant nutrients $(\mathrm{N}$ : $\mathrm{P}_{2} \mathrm{O}_{5}: \mathrm{K}_{2} \mathrm{O}$ ) were applied at 2 levels viz. $\mathrm{F}_{1}$ : 50\% RDF (10: 20: $10 \mathrm{~kg} \mathrm{ha}^{-1}$ ) and $\mathrm{F}_{2}: 100 \%$ RDF (20: 40: $20 \mathrm{~kg} \mathrm{ha}^{-1}$ ); 2 row spacing viz. $S_{1}: 30 \mathrm{~cm}$ and $S_{2}: 45 \mathrm{~cm}$; and 3 genotypes viz. $\mathrm{V}_{1}$ : HG-100, $\mathrm{V}_{2}$ : HG-8-1 and $\mathrm{V}_{3}$ : HG-563(c). The experiment was laid out in factorial randomized block design $(2 \times 2 \times 3)$ with 3 replications. All fertilizers as per treatment were applied at the time of sowing as basal and the crop was raised rainfed without any irrigation to simulate with the irrigation practice being followed by the farmers of that locality.

\section{Agronomic practices}

The land was ploughed followed by harrowing in criss-cross manner and the recommended dose of chemical fertilizers were added to each plot just before the final land preparation and levelling. Seeds of 3 genotypes were sown in solid rows at spacing of 30 and $45 \mathrm{~cm}$ between lines depending on different treatment combinations. Seedlings were thinned at 15 days after sowing (DAS) at $10 \mathrm{~cm}$ intra-row spacing. Two gentle hoeing and manual weeding operations were carried out at 26 and 40 DAS. No chemical plant protection measure was adopted due to lack of disease-pest incidence superseding economic threshold level. The plant population was counted at 15 DAS and at harvesting for yield estimation. No irrigation was applied to the experimental field so as to simulate the prevailing water management practices by the farmers of this region.

\section{Biometric observations}

The biometric observations were taken from the 5 selected plants in the either side of $3^{\text {rd }}$ row of each plot demarcated with proper 
pegging. The growth parameters like plant height and number of branches were recorded from these plants at regular intervals. However, for plant-biomass and leaf area index (LAI) destructive sampling procedure was followed averaging out the observations for 5 uprooted plants from the $3^{\text {rd }}$ row at opposite side of the plots meant for measuring plant height and branches.

Crop growth rate (CGR) was calculated by adopting the following formulae as suggested by Watson (1952).

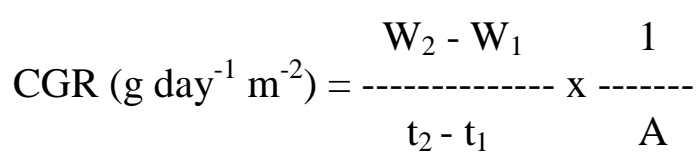

Where,

$\mathrm{W}_{1}=$ Dry weight of plant $(\mathrm{g})$ at time $\mathrm{t}_{1}$

$\mathrm{W}_{2}=$ Dry weight of plant $(\mathrm{g})$ at time $\mathrm{t}_{2}$

$\mathrm{t}_{2}-\mathrm{t}_{1}=$ Time interval in days

$\mathrm{A}=$ Unit area occupied by plants $\left(\mathrm{m}^{2}\right)$

The LAI at pod development was estimated by using the formulae suggested by Sestak et al., (1971) as follows.

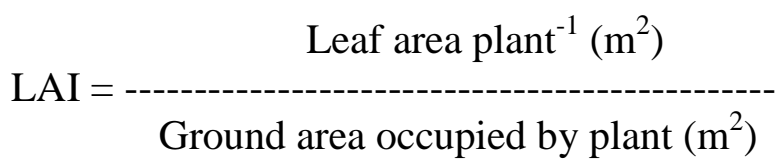

Before harvesting of the crop 5 tagged plants in each plot were taken out for recording the yield contributing characters. The grain yield was recorded by carefully harvesting the crop and subsequently threshing after its drying in the cemented floor.

\section{Statistical analysis}

The data collected were arranged in appropriate tables and analysed statistically by applying analysis of variance technique (AVNOVA) (Gomez et al., 1984). Standard error of means i.e. S.Em (+) were used in all cases. The significance of variance was tested by 'Error mean square' method of Fisher Snedecor's F-test at the probability level of 0.05 for appropriate degrees of freedom $(\mathrm{P}=0.05)$.

\section{Results and Discussion}

\section{Growth attributing characters}

\section{Plant height}

The plant height of cluster bean went on increasing with the advancement in crop age, irrespective of the treatments and reached its maximum at maturity (Table 1 and Fig.1). The rate of increase in plant height was the highest during 30 to 60 DAS and that were ensued by the rates during 60 to 90 DAS and 90 DAS to maturity in descending order. The main effect of fertility levels and varieties with respect to plant height was found significant at all the stages of crop growth except at 30 DAS.

Plants with 100\% RDF (20:40:20 kg ha $\left.\mathrm{kg}^{-1}\right)$ were taller than 50\% RDF (10:20:10 $\mathrm{kg} \mathrm{ha}^{-1}$ ) of $\mathrm{N}: \mathrm{P}_{2} \mathrm{O}_{5}: \mathrm{K}_{2} \mathrm{O}$ at 60,90 DAS and maturity. Row spacing had no significant influence on the plant height throughout the crop growth stages. However, plants with wider row spacing $(45 \mathrm{~cm})$ were relatively taller than closer row spacing $(30 \mathrm{~cm})$ at all the growth stages under observation. The cluster bean cv. HG-100 was the tallest among the 3 tested cultivars at 60, 90 DAS and maturity. There was no significant difference in plant height between cv. HG-100 and cv. HG-8-1 at maturity. Furthermore, cv. HG-563(c) was the shortest among 3 cultivars at all dates of observation.

\section{Number of branches}

The number of branches plant ${ }^{-1}$ was influenced significantly by fertility levels, 
row spacing and varieties at all the stages of cluster bean growth (Table 1 and Fig.1). There was continuous increase in the number of branches plant ${ }^{-1}$ up to 90 DAS and thereafter it remained static till maturity. Number of branches plant ${ }^{-1}$ increased significantly with increase in the levels of fertility. More branches were observed with $100 \%$ RDF (20:40:20 kg ha $\left.{ }^{-1}\right)$ than $50 \%$ RDF (10:20:10 $\left.\mathrm{kg} \mathrm{ha}^{-1}\right)$ of $\mathrm{N}: \mathrm{P}_{2} \mathrm{O}_{5}: \mathrm{K}_{2} \mathrm{O}$ at all growth stages. Significantly more branches plant $^{-1}$ were observed under row spacing of 45 $\mathrm{cm}$ compared to $30 \mathrm{~cm}$ at each crop growth stage. The cv. HG-100 recorded significantly the maximum number of branches plant $^{-1}$ among 3 cultivars at all stages of crop growth. However, at 30 and 60 DAS, it was at par with cv. HG-8-1.

The interaction effect of variety $\times$ spacing $(\mathrm{V} \times \mathrm{S})$ on number of branches plant ${ }^{-1}$ was found significant at 60 DAS (Table 1a). Cv. HG-100 sown with $45 \mathrm{~cm}$ row spacing i.e. $\mathrm{V}_{1} \mathrm{~S}_{2}$ produced the maximum number of branches plant ${ }^{-1}$ (5.80) among all treatment combinations.

\section{Plant biomass}

The plant-biomass of cluster bean increased continuously up to maturity under all treatments (Table 2 and Fig.1) and the rate of increase was more rapid between 60 to 90 DAS as compared to 30 to 60 DAS and 90 DAS to maturity.

Application of $100 \%$ RDF recorded significantly the higher plant-biomass of 2.05, 7.83, 28.08 and $46.39 \mathrm{~g}$ at 30, 60, 90 DAS and maturity, respectively compared to $50 \%$ RDF. The plant-biomass with $45 \mathrm{~cm}$ row spacing was significantly higher than $30 \mathrm{~cm}$ spacing at all crop growth stages. Significant superiority of cv. HG-100 over HG-8-1 and HG-563 (c) in biomass plant ${ }^{-1}$ was noticed at different stages of crop growth.

\section{Crop growth rate}

The crop growth rates (CGR) as influenced by different treatments at successive intervals of cluster bean crop growth have been presented in Table 2. The CGR increased up to 60 to 90 DAS of crop growth interval, but reduced remarkably beyond that.

The CGR during 0 to $30 \mathrm{DAS}, 30$ to $60 \mathrm{DAS}$, 60 to 90 DAS and 90 DAS to maturity of crop were significantly influenced by fertility levels. Application of $100 \%$ RDF recorded significantly the higher CGR than $50 \%$ RDF at all crop growth stages. The CGR did not vary statistically due to row spacing at all intervals of crop growth.

However, the crop with $30 \mathrm{~cm}$ row spacing recorded more CGR than $45 \mathrm{~cm}$ at latter crop growth intervals. Among the 3 varieties, cv. HG-100 registered relatively more CGR than cv. HG-8-1 and cv. HG-563 (c) throughout the crop growth intervals and the latter 2 cultivars did not differ statistically during 30 to 60 DAS and 60 to 90 DAS.

Among all interactions between experimental variables, the $\mathrm{F} \times \mathrm{V}$ at 30 and $60 \mathrm{DAS}$ were found significant with respect to CGR (Table $2 \mathrm{a}$ and $2 \mathrm{~b}$ ). At 30 DAS, cv. HG-100 recorded higher CGR than cv. HG-8-1 and HG-563(c) at both fertility levels. Significantly the highest CGR (3.009 $\mathrm{g}$ day $\left.^{-1} \mathrm{~m}^{-2}\right)$ was registered with $\mathrm{cv}$. HG-100 when fertilized with $100 \%$ RDF. At 60 DAS, cv. HG-8-1 with $100 \%$ RDF $\left(\mathrm{F}_{2} \mathrm{~V}_{2}\right)$ recorded the maximum CGR which was at par with $\mathrm{F}_{2} \mathrm{~V}_{3}$ and $\mathrm{F}_{1} \mathrm{~V}_{1}$.

\section{Leaf area}

The leaf area index (LAI) at pod development stage of cluster bean was influenced significantly due to fertility levels, row spacing and varieties (Table 2 and Fig.1). 
Table.1 Effect of fertility levels, row spacings and varieties on plant height and branches plant ${ }^{-1}$ of cluster bean at successive crop growth stages

\begin{tabular}{|c|c|c|c|c|c|c|c|c|}
\hline \multirow[t]{2}{*}{ Treatments } & \multicolumn{2}{|c|}{ Plant height (cm) at } & \multicolumn{6}{|c|}{ Branches plant ${ }^{-1}$ at } \\
\hline & 30 DAS & 60 DAS & 90 DAS & Maturity & 30 DAS & 60 DAS & 90 DAS & Maturity \\
\hline \multicolumn{9}{|l|}{ Fertility levels } \\
\hline $\mathrm{F}_{1}: 50 \% \mathrm{RDF}$ & 17.43 & $90.36^{\mathrm{b}}$ & $102.48^{b}$ & $112.49^{\mathrm{b}}$ & $2.10^{\mathrm{b}}$ & $4.73^{\mathrm{b}}$ & $9.31^{\mathrm{b}}$ & $9.31^{\mathrm{b}}$ \\
\hline $\mathrm{F}_{2}: 100 \% \mathrm{RDF}$ & 18.97 & $94.02^{\mathrm{a}}$ & $108.46^{\mathrm{a}}$ & $119.82^{\mathrm{a}}$ & $2.44^{\mathrm{a}}$ & $5.26^{\mathrm{a}}$ & $9.84^{\mathrm{a}}$ & $9.84^{\mathrm{a}}$ \\
\hline $\operatorname{S.Em}( \pm)$ & 0.53 & 0.84 & 1.64 & 2.19 & 0.05 & 0.09 & 0.12 & 0.12 \\
\hline $\mathrm{CD}(\mathrm{P}=0.05)$ & NS** & 2.46 & 4.80 & 6.43 & 0.13 & 0.26 & 0.35 & 0.35 \\
\hline \multicolumn{9}{|l|}{ Row Spacings } \\
\hline $\mathrm{S}_{1}: 30 \mathrm{~cm}$ & 17.78 & 90.99 & 103.83 & 115.12 & $2.19^{\mathrm{b}}$ & $4.78^{b}$ & $9.10^{\mathrm{b}}$ & $9.10^{\mathrm{b}}$ \\
\hline $\mathrm{S}_{2}: 45 \mathrm{~cm}$ & 18.62 & 93.38 & 107.10 & 117.19 & $2.36^{\mathrm{a}}$ & $5.21^{\mathrm{a}}$ & $10.06^{\mathrm{a}}$ & $10.06^{\mathrm{a}}$ \\
\hline S.Em $( \pm)$ & 0.53 & 0.84 & 1.64 & 2.19 & 0.05 & 0.09 & 0.12 & 0.12 \\
\hline $\mathrm{CD}(\mathrm{P}=0.05)$ & NS & NS & NS & NS & 0.13 & 0.26 & 0.35 & 0.35 \\
\hline \multicolumn{9}{|l|}{ Varieties } \\
\hline $\mathrm{V}_{1}:$ HG-100 & 18.85 & $101.38^{\mathrm{a}}$ & $115.13^{\mathrm{a} *}$ & $122.41^{\mathrm{a}}$ & $2.35^{\mathrm{a}}$ & $5.33^{\mathrm{a}}$ & $10.47^{\mathrm{a}}$ & $10.47^{\mathrm{a}}$ \\
\hline $\mathrm{V}_{2}: \mathrm{HG}-8-1$ & 18.28 & $89.97^{b}$ & $103.02^{\mathrm{ab}}$ & $117.19^{\mathrm{a}}$ & $2.32^{\mathrm{ab}}$ & $5.07^{\mathrm{a}}$ & $9.33^{\mathrm{b}}$ & $9.33^{\mathrm{b}}$ \\
\hline $\mathrm{V}_{3}:$ HG-563(c) & 17.47 & $85.22^{\mathrm{c}}$ & $98.25^{\mathrm{b}}$ & $108.87^{\mathrm{b}}$ & $2.15^{\mathrm{b}}$ & $4.58^{\mathrm{b}}$ & $8.93^{\mathrm{c}}$ & $8.93^{\mathrm{c}}$ \\
\hline S.Em $( \pm)$ & 0.65 & 1.03 & 2.00 & 2.69 & 0.06 & 0.11 & 0.15 & 0.15 \\
\hline $\mathrm{CD}(\mathrm{P}=0.05)$ & NS & 3.01 & 5.88 & 7.88 & 0.17 & 0.32 & 0.43 & 0.43 \\
\hline
\end{tabular}

* Means followed by common letters did not differ significantly up to 5\% level

** NS: Non-significant

Table.1a Effect of $\mathrm{V} \times \mathrm{S}$ on number of branches plant ${ }^{-1}$ at $60 \mathrm{DAS}$

\begin{tabular}{lcccc}
\hline Treatments & & \multicolumn{3}{c}{ Varieties } \\
\cline { 3 - 5 } & & $\mathbf{V}_{\mathbf{1}}$ & $\mathbf{V}_{\mathbf{2}}$ & $\mathbf{V}_{\mathbf{3}}$ \\
\hline Row & $\mathbf{S}_{\mathbf{1}}$ & $4.87^{\mathrm{bcd}}$ & $4.97^{\mathrm{bc}}$ & $4.50^{\mathrm{d}}$ \\
spacings & $\mathbf{S}_{\mathbf{2}}$ & $5.80^{\mathrm{a}}$ & $5.17^{\mathrm{b}}$ & $4.67^{\mathrm{cd}}$ \\
\hline S.Em $( \pm)$ & & & 0.15 & \\
CD $(\mathrm{P}=0.05)$ & & & 0.45 & \\
\hline
\end{tabular}

* Means followed by common letters did not differ significantly up to 5\% level

Table.2 Effect of fertility levels, row spacings and varieties on biomass plant ${ }^{-1}$, CGR and LAI of cluster bean at successive crop growth stages

\begin{tabular}{|c|c|c|c|c|c|c|c|c|c|}
\hline \multirow[t]{2}{*}{ Treatments } & \multicolumn{4}{|c|}{ Biomass plant $^{-1}(\mathrm{~g})$ at } & \multicolumn{4}{|c|}{$C G R\left(g \operatorname{day}^{-1} m^{-2}\right)$} & \multirow[b]{2}{*}{ 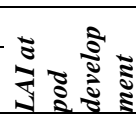 } \\
\hline & 30 DAS & 60 DAS & 90 DAS & Maturity & $\begin{array}{c}\text { 0 to } 30 \\
\text { DAS }\end{array}$ & $\begin{array}{c}30 \text { to } 60 \\
\text { DAS }\end{array}$ & $\begin{array}{c}60 \text { to } 90 \\
\text { DAS } \\
\end{array}$ & 90 to maturity & \\
\hline \multicolumn{10}{|l|}{ Fertility levels } \\
\hline $\mathrm{F}_{1}: 50 \% \mathrm{RDF}$ & $1.72^{\mathrm{b}}$ & $7.20^{\mathrm{b}}$ & $25.57^{\mathrm{b}}$ & $42.26^{\mathrm{b}}$ & $1.870^{\mathrm{b}}$ & $5.950^{\mathrm{b}}$ & $20.046^{\mathrm{b}}$ & $13.698^{\mathrm{b}}$ & $0.853^{\mathrm{b}}$ \\
\hline $\mathrm{F}_{2}: 100 \% \mathrm{RDF}$ & $2.05^{\mathrm{a}}$ & $7.83^{\mathrm{a}}$ & $28.08^{\mathrm{a}}$ & $46.39^{\mathrm{a}}$ & $2.285^{\mathrm{a}}$ & $6.515^{\mathrm{a}}$ & $22.664^{\mathrm{a}}$ & $15.359^{\mathrm{a}}$ & $1.030^{\mathrm{a}}$ \\
\hline S.Em $( \pm)$ & 0.05 & 0.14 & 0.41 & 0.65 & 0.058 & 0.079 & 0.290 & 0.271 & 0.030 \\
\hline $\mathrm{CD}(\mathrm{P}=0.05)$ & 0.15 & 0.40 & 1.21 & 1.90 & 0.169 & 0.231 & 0.850 & 0.794 & 0.089 \\
\hline \multicolumn{10}{|l|}{ Row Spacings } \\
\hline $\mathrm{S}_{1}: 30 \mathrm{~cm}$ & $1.58^{\mathrm{b}}$ & $6.48^{\mathrm{b}}$ & $23.20^{\mathrm{b}}$ & $38.36^{\mathrm{b}}$ & 2.039 & 6.335 & 21.577 & 14.679 & $0.881^{\mathrm{b}}$ \\
\hline$S_{2}: 45 \mathrm{~cm}$ & $2.18^{\mathrm{a}}$ & $8.55^{\mathrm{a}}$ & $30.45^{\mathrm{a}}$ & $50.28^{\mathrm{a}}$ & 2.117 & 6.130 & 21.133 & 14.378 & $1.002^{\mathrm{a}}$ \\
\hline S.Em $( \pm)$ & 0.05 & 0.14 & 0.41 & 0.65 & 0.058 & 0.079 & 0.290 & 0.271 & 0.030 \\
\hline $\mathrm{CD}(\mathrm{P}=0.05)$ & 0.15 & 0.40 & 1.21 & 1.90 & NS** & NS & NS & NS & 0.089 \\
\hline \multicolumn{10}{|l|}{ Varieties } \\
\hline $\mathrm{V}_{1}:$ HG-100 & $2.30^{\mathrm{a}}$ & $8.03^{\mathrm{a}}$ & $28.23^{\mathrm{a}}$ & $48.84^{\mathrm{a}}$ & $2.550^{\mathrm{a}}$ & $6.393^{\mathrm{a}}$ & $22.514^{\mathrm{a}}$ & $17.234^{\mathrm{a}}$ & $1.021^{\mathrm{a}}$ \\
\hline $\mathrm{V}_{2}: \mathrm{HG}-8-1$ & $1.78^{\mathrm{b}}$ & $7.45^{\mathrm{b}} *$ & $26.63^{\mathrm{ab}}$ & $43.08^{\mathrm{b}}$ & $1.952^{\mathrm{b}}$ & $6.271^{\mathrm{ab}}$ & $21.148^{\mathrm{b}}$ & $13.692^{\mathrm{b}}$ & $0.945^{\mathrm{ab}}$ \\
\hline $\mathrm{V}_{3}:$ HG-563(c) & $1.58^{\mathrm{c}}$ & $7.08^{\mathrm{b}}$ & $25.63^{\mathrm{b}}$ & $41.06^{\mathrm{b}}$ & $1.732^{\mathrm{c}}$ & $6.033^{\mathrm{b}}$ & $20.402^{\mathrm{b}}$ & $12.660^{\mathrm{b}}$ & $0.859^{\mathrm{b}}$ \\
\hline S.Em $( \pm)$ & 0.06 & 0.17 & 0.51 & 0.79 & 0.071 & 0.097 & 0.355 & 0.331 & 0.037 \\
\hline $\mathrm{CD}(\mathrm{P}=0.05)$ & 0.18 & 0.49 & 1.48 & 2.33 & 0.207 & 0.283 & 1.041 & 0.972 & 0.109 \\
\hline
\end{tabular}

* Means followed by common letters did not differ significantly up to $5 \%$ level

** NS: Non-significant 
Table.2a Effects of $\mathrm{F} \times \mathrm{V}$ on CGR at $30 \mathrm{DAS}$

\begin{tabular}{lcccc}
\hline \multicolumn{2}{c}{ Treatments } & \multicolumn{3}{c}{ Varieties } \\
\cline { 3 - 5 } & & $\mathbf{V}_{\mathbf{1}}$ & $\mathbf{V}_{\mathbf{2}}$ & $\mathbf{V}_{\mathbf{3}}$ \\
\hline \multirow{2}{*}{ Fertility levels } & $\mathbf{F}_{\mathbf{1}}$ & $2.091^{\mathrm{b}}$ & $1.832^{\mathrm{bc}}{ }^{\mathrm{a}}$ & $1.688^{\mathrm{c}}$ \\
& $\mathbf{F}_{\mathbf{2}}$ & $3.009^{\mathrm{a}}$ & $2.072^{\mathrm{b}}$ & $1.775^{\mathrm{c}}$ \\
\hline S.Em $( \pm)$ & & & 0.100 & \\
$\mathrm{CD}(\mathrm{P}=0.05)$ & & & 0.293 & \\
\hline
\end{tabular}

* Means followed by common letters did not differ significantly up to 5\% level

Table.2b Effect of F×V on CGR at 60 DAS

\begin{tabular}{lcccc}
\hline & Treatments & \multicolumn{3}{c}{ Varieties } \\
\cline { 3 - 5 } & & $\mathbf{V}_{\mathbf{1}}$ & $\mathbf{V}_{\mathbf{2}}$ & $\mathbf{V}_{\mathbf{3}}$ \\
\hline \multirow{2}{*}{ Fertility levels } & $\mathbf{F}_{\mathbf{1}}$ & $6.487^{\mathrm{ab}} *$ & $5.801^{\mathrm{c}}$ & $5.561^{\mathrm{c}}$ \\
& $\mathbf{F}_{\mathbf{2}}$ & $6.300^{\mathrm{b}}$ & $6.741^{\mathrm{a}}$ & $6.506^{\mathrm{ab}}$ \\
\hline S.Em $( \pm)$ & & & 0.137 & \\
$\mathrm{CD}(\mathrm{P}=0.05)$ & & & 0.401 & \\
\hline
\end{tabular}

* Means followed by common letters did not differ significantly up to $5 \%$ level

Table.3 Effect of fertility levels, row spacings and varieties on yield attributing characters of cluster bean

\begin{tabular}{|c|c|c|c|c|c|c|}
\hline Treatments & $\begin{array}{l}\text { Pods } \\
\text { plant }^{-1}\end{array}$ & $\begin{array}{l}\text { Pod length } \\
(\mathrm{cm})\end{array}$ & Seeds pod & $\begin{array}{l}\text { 1000'seed } \\
\text { weight }(g)\end{array}$ & $\begin{array}{l}\text { Seed yield } \\
\left(\text { g plant }^{-1}\right)\end{array}$ & $\begin{array}{l}\text { Seed yield (kg } \\
\left.\mathrm{ha}^{-1}\right)\end{array}$ \\
\hline \multicolumn{7}{|l|}{ Fertility levels } \\
\hline$\overline{\mathrm{F}_{1}: 50 \% \mathrm{RDF}}$ & $85.82^{b}$ & 5.44 & $8.08^{\mathrm{b}}$ & 34.42 & $9.46^{\mathrm{b}}$ & $2204^{\mathrm{b}}$ \\
\hline $\mathrm{F}_{2}: 100 \% \mathrm{RDF}$ & $92.46^{\mathrm{a}}$ & 5.46 & $8.50^{\mathrm{a}}$ & 34.83 & $10.03^{\mathrm{a}}$ & $2314^{\mathrm{a}}$ \\
\hline $\operatorname{S.Em}( \pm)$ & 1.94 & 0.06 & 0.13 & 0.42 & 0.12 & 30.59 \\
\hline $\mathrm{CD}(\mathrm{P}=0.05)$ & 5.68 & $\mathrm{NS}^{* *}$ & 0.38 & NS & 0.36 & 89.72 \\
\hline \multicolumn{7}{|l|}{ Row Spacings } \\
\hline $\mathrm{S}_{1}: 30 \mathrm{~cm}$ & $85.52^{b}$ & 5.42 & 8.27 & 34.40 & $9.38^{\mathrm{b}}$ & $2021^{b}$ \\
\hline $\mathrm{S}_{2}: 45 \mathrm{~cm}$ & $92.76^{\mathrm{a}}$ & 5.48 & 8.31 & 34.85 & $10.11^{\mathrm{a}}$ & $2497^{\mathrm{a}}$ \\
\hline S.Em $( \pm)$ & 1.94 & 0.06 & 0.13 & 0.42 & 0.12 & 30.59 \\
\hline $\mathrm{CD}(\mathrm{P}=0.05)$ & 5.68 & NS & NS & NS & 0.36 & 89.72 \\
\hline \multicolumn{7}{|l|}{ Varieties } \\
\hline $\mathrm{V}_{1}: \mathrm{HG}-100$ & $95.77^{\mathrm{a}}$ & $5.63^{\mathrm{a}}$ & 8.47 & 35.23 & $10.60^{\mathrm{a}}$ & $2476^{\mathrm{a}}$ \\
\hline $\mathrm{V}_{2}:$ HG-8-1 & $87.73^{b} *$ & $5.36^{\mathrm{b}}$ & 8.33 & 34.55 & $9.93^{b}$ & $2204^{b}$ \\
\hline $\mathrm{V}_{3}: \mathrm{HG}-563(\mathrm{c})$ & $83.92^{b}$ & $5.36^{\mathrm{b}}$ & 8.07 & 34.10 & $8.73^{c}$ & $2097^{\mathrm{b}}$ \\
\hline S.Em $( \pm)$ & 2.37 & 0.07 & 0.16 & 0.51 & 0.15 & 37.46 \\
\hline $\mathrm{CD}(\mathrm{P}=0.05)$ & 6.96 & 0.21 & NS & NS & 0.44 & 109.88 \\
\hline
\end{tabular}

* Means followed by common letters did not differ significantly up to 5\% level

** NS: Non-significant 
Fig.1 Growth attributes as influenced by different treatments

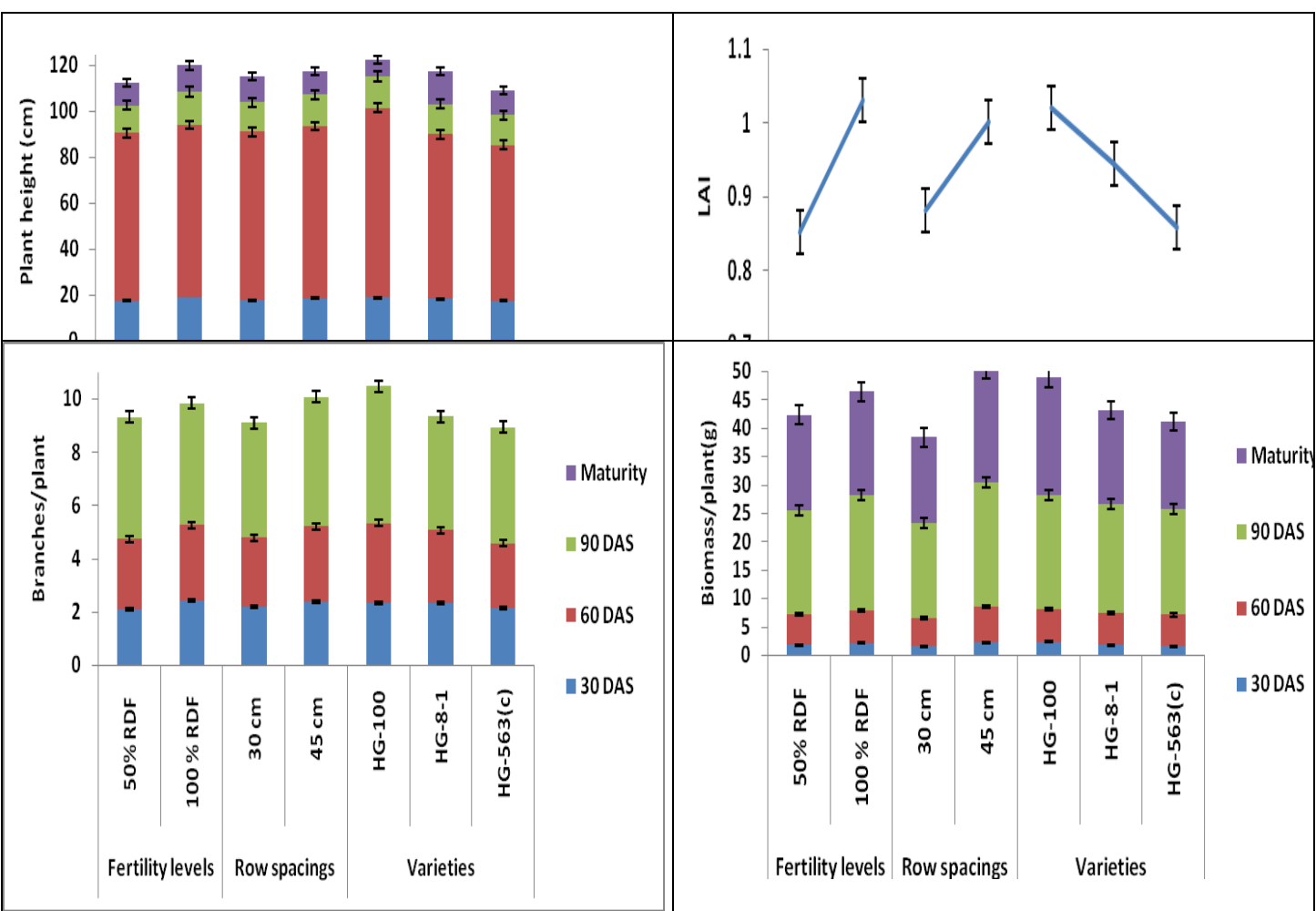

Fig.2 Yield attributes as influenced by different treatments

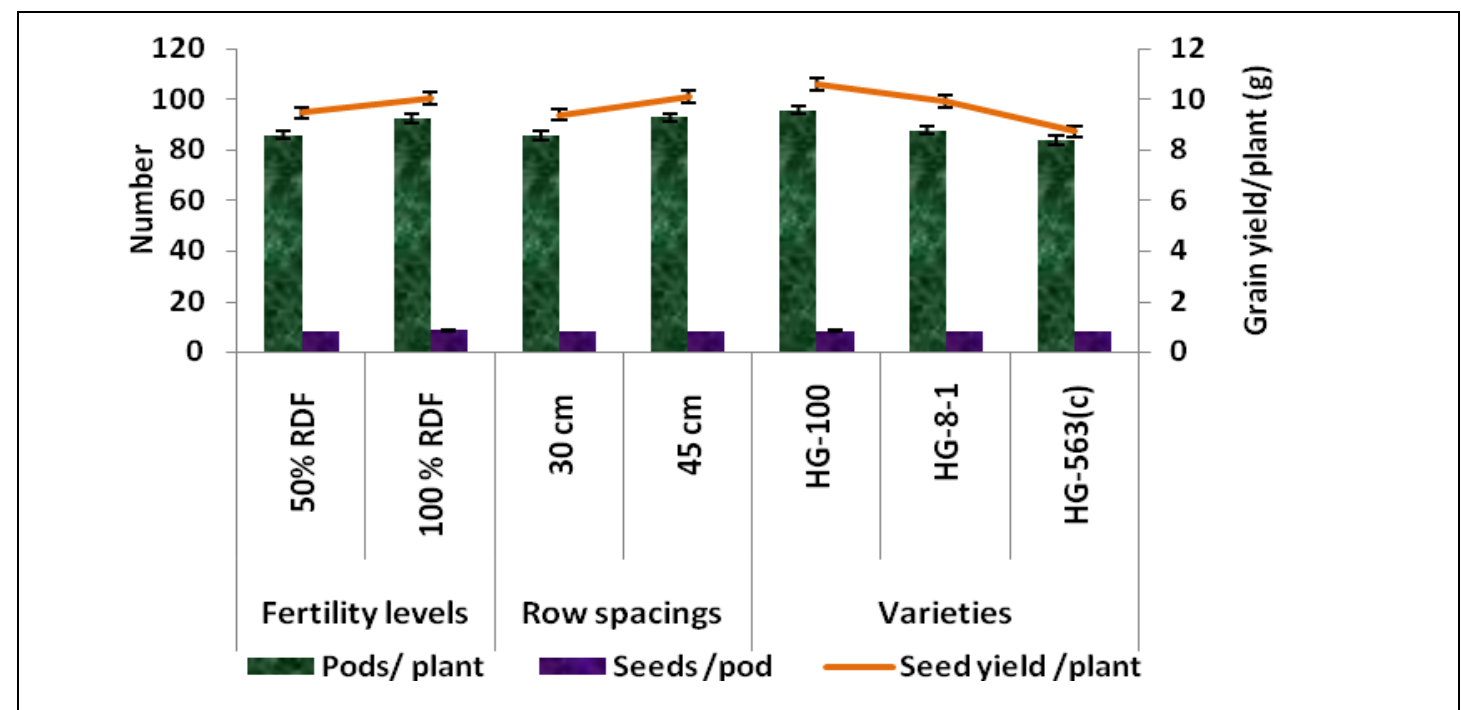

Application of $100 \%$ RDF recorded the maximum LAI of 1.03 , which was $20.75 \%$ more than that of $50 \%$ RDF. Crop sown with $45 \mathrm{~cm}$ row spacing resulted in significantly higher LAI than crop spaced at $30 \mathrm{~cm}$ rows. The cv. HG-100 registered significantly higher LAI than cv. HG-563 (c) but was at par with cv. HG-8-1. 


\section{Yield attributing characters}

\section{Number of pods}

Cluster bean applied with $100 \%$ RDF recorded significantly more number of pods plant $^{-1}$ (92.46) than 50\% RDF (Table 3 and Fig.2). Row spacing of $45 \mathrm{~cm}$ significantly enhanced the pods plant ${ }^{-1}$ over $30 \mathrm{~cm}$ spacing. Among 3 cultivars, cv. HG-100 being at par with cv.HG-8-1 produced significantly higher number of pods plant ${ }^{-1}$ than $\mathrm{cv}$. HG-563(c).

\section{Pod length}

Application of 100\% RDF produced longer pods than $50 \%$ RDF but without significant difference (Table 3). Crop sown with $45 \mathrm{~cm}$ row spacing produced relatively longer but at par pods compared to crop sown at $30 \mathrm{~cm}$ spacing. Cv. HG-100 produced significantly longer pods than cv. HG-8-1 and cv. HG-563 (c) having same pod length of $5.36 \mathrm{~cm}$.

\section{Number of seeds pod ${ }^{-1}$}

Application of $100 \%$ RDF resulted in significantly more number of seeds pod $^{-1}(8.5)$ than 50\% RDF (Table 3 and Fig.2). However, row spacings and varieties had no significant effect on seeds pod ${ }^{-1}$.

\section{0' seed weight}

The study of 1000' seed weight (Table 3) revealed no significant difference due to the effect of fertility levels, row spacing and varieties of cluster bean under consideration.

\section{Seed yield plant ${ }^{-1}$}

The seed yield of cluster bean (10.03 g plant ${ }^{-1}$ and $2314 \mathrm{~kg} \mathrm{ha}^{-1}$ ) was significantly higher in plots receiving $100 \%$ RDF than the crop grown with 50\% RDF (Table 3 and Fig.2). Wider row spacing of $45 \mathrm{~cm}$ resulted in significantly better seed yield $\left(10.11 \mathrm{~g}\right.$ plant $^{-1}$ and $2497 \mathrm{~kg} \mathrm{ha}^{-1}$ ) compared to $30 \mathrm{~cm}$ spacing. The 3 varieties of cluster bean had significantly different seed yield with diminishing order of cv. HG-100, cv. HG-8-1 and cv. HG-563 (c). Cv. HG-100 had the highest seed yield (10.6 g plant ${ }^{-1}$ and $2476 \mathrm{~kg}$ $\mathrm{ha}^{-1}$ ) and cv. HG-563 (c) had the lowest. The grain yield of HG-100 was $12.34 \%$ and 18.07 $\%$ higher than HG-8-1 and HG-563(c), respectively.

The overall improvement in the growth of cluster bean at higher level of fertility could be ascribed to their pivotal role in several physiological and biochemical processes, viz., root development, photosynthesis, energy transfer reaction and symbiotic biological Nfixation process. The earlier observations in this line by Rathore et al., (2007) and Yadav et al., (1991) in cluster bean, by Patra (1991) and Arya and Singh (1996) in horse gram and by Shubhra et al., (2003), Bhadoria and Kushwah (2005) and Muhammad et al., (2009) in legume crops influenced by soil fertility were in conformity with the present results.

More number of branches and higher plantbiomass, greater CGR and LAI of cluster bean with wider row spacing $(45 \mathrm{~cm})$ might be due to availability of larger area for better crop growth and supply of plant nutrients in adequate quantities. Similar results have been reported by Rajput (2002), and Bhadoria and Kushwaha (2005).

Significant varietal differences were noticed for plant height, number of branches plant ${ }^{-1}$, biomass plant ${ }^{-1}$, CGR and LAI at all the stages of observation except plant height at 30 DAS. Cv. HG-100 had the highest value of all these growth characters followed by cv.HG-81. The differential behaviour of cluster bean varieties with respect to these characters could be explained solely by the variation in 
their genetic makeup and adaptability to soil and climatic conditions. The results are in close conformity with the findings of Vyas (2002) who reported that the late genotypes had better vegetative growth in terms of plant height.

Each plant passes through the vegetative as well as reproductive phases of growth to complete its life cycle. Yield can be considered to be the final expression of the physiological and metabolic activities of plants and is governed by various factors. These yield attributing factors viz. number of pods plant ${ }^{-1}$, pod length, number of seeds pod $^{-1}, 1000^{\prime}$ seed weight and seed yield plant ${ }^{-1}$ have direct bearing on plant productivity and for increasing the yield that play important roles.

Application of $100 \%$ RDF could have influenced such yield attributes due to efficient availability of suitable plant nutrients in adequate quantities, better partitioning of metabolites and adequate translocation of photosynthates to developing reproductive structures. However, the yield attributing characters like pod length and 1000' seed weight remained unchanged due to fertility levels possibly due to genetic makeup. These results confirmed the findings of Patra (1991), Rafey and Srivastava (1989), Yadav et al., (1991), Arya and Singh (1996), Choudhary et al., (2003), Meena and Naagar (2004), Bhadoria and Kushwah (2005), Rathore et al., (2007) and Muhammad et al., (2009).

Wider row spacing of $45 \mathrm{~cm}$ resulted in significantly higher number of pods plant $^{-1}$, number of seeds plant ${ }^{-1}$ and seed yield plant ${ }^{-1}$ as compared to closer row spacing $(30 \mathrm{~cm})$. This might be due to better penetration of light, free air circulation to the lower layers of the crop canopy and reduction of inter-row crop competition (Rana et al., 1991; Yadav et al., 1992; Bhadoria and Chauhan, 1994; Singh and Tiwana, 1995; and Sheoran and Rana, 2007).

Superiority of cv. HG-100 over other 2 cultivars in recording better yield attributes could be ascribed to inherent genetic ability for efficient utilization of available resources and further translocation of such nutrients and photosynthates to reproductive parts. The present result corroborated the earlier findings of Yadav et al., (1992), Bhadoria and Kushwah (2005), Choudhary et al., (2005), Singh et al., (2005) and Sheoran and Rana (2007). Application of 100\% RDF had better response on growth and yield attributing characters viz. plant height, number of branches, plant-biomass, LAI, number of pods plant ${ }^{-1}$ and seeds pod ${ }^{-1}$ than $50 \%$ RDF in cluster bean. These parameters had also shown positive results under wider row spacing of $45 \mathrm{~cm}$ than $30 \mathrm{~cm}$ and cv. HG-100 was observed to be the most promising variety irrespective of fertility levels and row spacings compared to $\mathrm{cv}$. HG-8-1 and $\mathrm{cv}$. HG-563(c). The combined effects of growth and yield contributing characters were ultimately reflected in production of the highest seed yield by sowing of cluster bean cv. HG-100 at $45 \mathrm{~cm}$ row spacing and with $100 \%$ RDF which should be recommended for the farmers of Gird region of Madhya Pradesh, India during kharif.

\section{Acknowledgements}

The technical and informative supports of the College of Agriculture, Rajmata Vijayaraja Scindia Krishi Vishwa Vidyalaya, Gwalior, Madhya Pradesh, India for conducting such post-graduation field research of the first author are highly acknowledged. The last two authors were directly and / or indirectly associated with the planning and execution of the experiment, statistical and chemical analyses, writing of this paper basing on the research outcomes of the first author. 


\section{Abbreviations}

RDF: Recommended dose of fertilizers

DAS: Days after sowing

\section{Conflict of interest}

There is no conflict of interest among the 3 authors.

\section{Ethical approval}

This article does not contain any studies with human participants or animals performed by any of the authors.

\section{References}

Arya, M. P. S. and Singh, R. 1996. Effect of $\mathrm{N}, \mathrm{P}$ and $\mathrm{K}$ on the nodulation, growth and yield characters of horse gram (Macrotyloma uniflorum Lum. Verdc.). Legume Research, 19(2): 65-69.

Bhadoria, R. B. S. and Chauhan, D. V. S. 1994. Response of cluster bean (Cyamopsis tetragonoloba) to date of sowing and spacing. Indian Journal of Agronomy, 39(1): 156-157.

Bhadoria, R. B. S. and Kushwah, R. S. 2005. Response of clusterbean (Cyamopsis tetragonoloba) varieties to varying fertility levels and row spacing in northern Madhya Pradesh. National Symposium on Advances in Forage Research and Sustainable Animal production, held at CCSHAU, Hissar, pp. 106.

Choudhary, G. R., Dahama, A. K., Reager, M. L. 2003. Effect of weed control and phosphorus on yield attributes and yield of clusterbean [Cyamopsis tetragonoloba (L.) Taub.]. Current Agriculture, 27(1/2): 143-145.

Gomez, K. A. and Gomez, A. A. 1984. Statistical procedures for agricultural research. Second edition. Wiley India. pp. 200-206.

Meena, N. L. and Naagar, K. C. 2004. Effect of phosphorus, sulphur and phosphate solubilizing bacteria on yield components, yield and quality of cluster bean [Cyamopsis tetragonoloba (L.) Taub.], Legume Research, 27(1): 27-31

Muhammad, S., Ahmed, I. and Abdur, R. 2009. Effect of nitrogen levels on the yield and yield component of guar gum (Cyamopsis tetragonoloba). American Eurasian Journal of Sustainable Agriculture, 3(1): 29-32.

Patra, S. S.1991. Response of horse gram (Macrotyloma uniflorum) to date of sowing and fertilizer under rainfed condition. Indian Journal of Agronomy, 36: 296-297.

Priyadarshini, S., Rawat, G. S. and Dwibedi, S. K. 2017. Performance of some promising genotypes of cluster bean (Cyamopsis tetragonoloba L. Tabu) under varying levels of primary plant nutrients and row spacing. International Journal of Agriculture Sciences, 9(44): 4722-4724.

Rajput, R. S. 2002. Response of cluster bean (Cyamopsis tetragonoloba L. Taub) varieties to varying fertility level and row spacing in northern Madhya Pradesh. M. Sc. (Ag.) in Agronomy thesis, JNKVV, Jabalpur.

Rana, D. S., Yadav, B. D., Dhukia, R. S. and Midha, L. K. 1991. Effect of row spacing and intra-row spacing on seed yield of cluster bean under late sown conditions. Guar Research Annals, 7: 54-56.

Rathore, V. S., Singh, J. P., Soni, M. L. and Beniwal, R. K. 2007. Effect of nutrient management on growth, productivity and nutrient uptake of rainfed cluster bean (Cyamopsis tetragololoba) in arid region. Indian Journal of Agricultural Sciences, 77(6): 349-53.

Refey, A. and Srivastava, V. C. 1989. 
Agronomic management of late sown horse gram. Indian Journal of Agronomy, 34(4): 461-463.

Sheoran, R. S. and Rana, D. S. 2007. Evaluation of forage cowpea varieties for seed production under different row spacings. Forage Research, 32(4): 243244.

Shubhra, Dayal, J. and Goswami C. L. 2003. Effect of phosphorus application on growth, chlorophyll and proline under water deficit in cluster bean (Cyamopsis tetragonoloba L. Taub). Indian Journal of Plant Physiology, 8(2): 150-154.

Singh, H. and Tiwana, U. S. 1995. Response of guar (Cyamopsis tetragonoloba $\mathrm{L}$. Taub) varieties to varying level of phosphorus and row spacing. Indian Journal of Agricultural Research, 29(1): 49-52.

Singh, N. P., Singh, R. V., Choudhary, S. P. S., Khedar, O. P. and Saini, D. D. 2005. Breeding dual type guar varieties for arid zone. National Symposium on Advances in Forage Research and
Sustainable Animal production, held at CCSHAU, Hissar, pp. 18.

Taneja, K. D., Gill, P. S. and Sharma, B. D. 1982. Effects of row spacing and intrarow spacing on seed yield of guar cultivars. Forage Research, 8(2): 111115.

Vyas, S. P. 2002. Response of early and late cluster bean genotypes under field droughts at Bhuj. National Symposium on Arid legumes for Food, Nutrition Security and Promotion of Trade, May 15-16. pp. 116-117.

Yadav, B. D., Agrawal, S. K. and Faroda, A. S. 1991. Dry matter accumulation and nutrient uptake in cluster bean as affected by row spacing and fertilizer application. Forage Research, 17(1): 3944.

Yadav, B. D., Joon, R. K. and Sheoran, R. S. 1992. Response of cluster bean to dates of sowing and row spacing under rainfed conditions. Forage Research, 18(2): 157-159.

\section{How to cite this article:}

Sasmita Priyadarshini, Ghanashyam Singh Rawat and Sanat Kumar Dwibedi. 2017. Effects of Levels of Primary Plant Nutrients and Row Spacing on Growth and Yield Attributes of Some Promising Varieties of Cluster Bean (Cyamopsis tetragonoloba L.). Int.J.Curr.Microbiol.App.Sci. 6(12): 17-27. doi: https://doi.org/10.20546/ijcmas.2017.612.003 